\title{
Learning the Russian Language in the Game:
}

\section{Traditional and New Approaches}

\author{
Julia Vladimirovna Kapralova ${ }^{1}$, Lada Alekseevna Moskaleva ${ }^{1}$ \& Iana Arthurovna Byiyk ${ }^{2}$ \\ ${ }^{1}$ Kazan Federal University, Russia \\ ${ }^{2}$ Cambridge College of English, British \\ Correspondence: Julia Vladimirovna Kapralova, Kazan Federal University, Russia. E-mail: afina.pallada@mail.ru
}

Received: July 17, 2019

Accepted: October 12, 2019

Online Published: October 28, 2019

doi:10.5430/ijhe.v8n7p50

URL: https://doi.org/10.5430/ijhe.v8n7p50

\begin{abstract}
The article deals with the traditional game approaches that have well recommended themselves at the lessons of the Russian language, and their potential and ways of modifying into a single game space of the lesson is being discussed. Basing on personal experience, the authors of the article present the possibilities of organizing a Russian language lesson in the form of a quest. Many experts rightly paid attention to the effectiveness of using games in the learning process. Despite the attractiveness for teachers and students, until recently, game approaches as a form of education have remained on the periphery of the educational process, being just a supplement to the main methods. Only role-playing games can be called an exception, with their being included both in the educational process of school and university education, and in professional-oriented training of specialists. However, under the influence of processes in modern culture and the active development of gaming technology, the "gamification" of education acquires the character of a mass phenomenon both at school and in higher educational institutions, and ignoring these processes is not only impossible but impractical. In this regard, the article provides a scientific and methodological understanding of this form of education and identifies the structural peculiarities of the quest unlike the other game forms. The article is addressed to teachers of Russian as a foreign language and can be used as a kind of model for conducting quests in classes both in various courses on grammar, reading, writing, listening, linguistic and cultural studies, and in students' independent educational activities.
\end{abstract}

Keywords: lesson as a quest, game tasks, didactic game, teaching methods, Russian as a foreign language

\section{Introduction}

An educational quest (a lesson-quest) can be defined as a type of a didactic adventure game of a complex organization, in which individual puzzle tasks are arranged in a cause-effect chain and are combined by a plot and ultimate goal.

In the process of completing the quest by the quest players, the existing knowledge is activated and the new one is acquired. Pedagogical technology in one way or another is aimed at the implementation of scientific ideas, conditions, theories in practice, being also focused on the assimilation and consolidation of knowledge, education and development (improvement) of natural personal qualities, on searching for the most effective techniques in the context of a communicative approach, the interest in which does not weaken in either the Russian or foreign methodology (in particular, [Litdewood W. 2002; Marsha L. 2002; Varlamova M. Yu., Miftakhova A. N., Bochina 2016; Galiulina I.R., Yapparova V.N., Starostina O.V. 2016; Elena A. Makleeva, Liana M. Akhmetzyanova, Yan Zhike 2018; Alpeisso et al, 2018]).

To be effective as an element of the language learning process, a quest must represent a type of the complex lesson combining the training of all types of speech activity, while meeting such parameters as language proficiency; the presence of communicative and educational objectives of learning; the presence of a number of specific educational tasks, based on the types of speech activity being trained and on the language aspects; linguistic studies and linguistic culturology components that ensure interest in the quest plot (in particular, [Bochina T., Adamka P. 2015; Baroughi \& ZAREI, 2013; Vargas et al, 2019]).

Language material (phonetics, word-formation, lexical, grammar) becomes the direct building material of the tasks, providing both the challenge itself, and the game mechanics, the cause-effect relationships of the quest. 
This article offers some tasks for the most important sections of the Russian language, which involve searching, logic, and active action; with the tasks being able to unite into a single chain of tasks under a common legend. As a result, you can get the learning quest as the clearly built one and affecting the most important aspects of learning Russian as a foreign language.

The article gives a structural model of forming the quest: a section in accordance with the aspect of learning the Russian language (with methodical recommendations), options for game tasks that are consistently arranged into a single quest under a common legend (formulated by the teacher).

\section{Materials and Methods}

In order to clearly represent the tasks and skills being formed or controlled by a specific task, all tasks are divided according to the types of speech activity and aspects of teaching: reading, writing, listening, speaking; grammar (by relevant topics), vocabulary, word formation, phonetics, linguistic and cultural studies, stylistics, communication practice.

1. Phonetics. Quest tasks based on phonetic material, set as the main goal such interaction of the participants, when the speed and the result of passing the test depend on the correct reproduction of the sound range [The man playing ..., p. 21]. Such tasks can be, for example, "packed" in the legend of disclosing the meaning of the cipher and become part of an adventure quest.

2. Graphics and spelling. Teaching graphics and spelling includes developing the skill of graphically correct writing. Game tasks aimed at drawing attention to the graphic appearance of the word and spelling, at working out sound-letter correspondences, at distinguishing cursive and typed variants of letters are extremely important even at an advanced stage, when systematic training in graphics and spelling is much more complicated or, in principle, can't be possible in terms of time [The man playing ..., p. 36].

3. Vocabulary. Phraseology. Quest situations create conditions for the activation and consolidation of thematic lexical material not by repeating the words themselves, but by maintaining and strengthening the previously formed skills for using words to generate and recognize a statement. The fascination of the process and the accompanying visual and kinesthetic effects firmly fix the vocabulary in the mind of the player [The man playing ..., p. 46].

The range of applying such tasks is very wide, since the vocabulary is the most obvious building material of the lesson-quests.

4. Grammar: morphology and syntax. According to the theory of Russian as a foreign language grammar is considered to be a necessary base, without which a foreign language is impossible to be fully used as a means of communication. Grammar represents itself as a formal system consisting of morphology, syntax and word formation, which can be called subsystems of the grammatical structure of the language [Savchenko, p. 21]. In game quest tasks, it is advisable to introduce grammar implicitly, in unity with the thematic vocabulary or in accordance with a specific communicative task, through practice in speech. This allows to make a connection from the linguistic competence (knowledge of morphology, syntax, word formation) to the speech competence (the skills to correctly build the speech according to the grammatical patterns), followed by the communication competence (ability to communicate in a variety of situations) [The man playing ..., p. 68].

Such tasks are the most successful for organizing the search, for orientating participants between the locations of the quest, for orientating on the map.

5. Reading and listening. Reading is the main form of presenting instructions for passing the tests as well asbeing the main channel of interaction between participants and organizers of the game. Also, most of the quests, especially of linguistic and cultural orientation, is based on acquainting with the history of the place, monuments, personality, where the written text appears in different variations: from the exhibits' signs to a detailed description of events. In this regard, the form of the quest becomes extremely productive for training various types of reading (scanning, studying, searching and acquainting).

Listening as a component of oral speech communication is a complex mental process of percepting and understanding of speech by ear, as a result of which the listener comes to certain conclusions [The man playing .., p. 88].

6. Writing and speaking. Communication. The main goal of the quest tasks aimed at developing speech and communicative competence is to overcome the psychological barriers associated with speaking, when the focus of the players'attention in the excitement of the game is shifted from the challenging educational goal of producing the statement to the game goal. 
In the process of passing the quest, the players can also supplement their own information and repertoire of speech models, rules of communication, national and cultural peculiarities of the country of the studied language. As for writing, it is less common in quest tasks because of the need to quickly solve communication problems. However, it is possible to include tasks for training the writing skills by means of creating such conditions for participants, when direct oral transmitting information is impossible.

\section{Results and Discussion}

Basing on the above principles, the authors create interactive lessons, which often imply going out of town, to the famous historical places known by their history. As an example, we give one of the quests - "Raifa: the gate to the past."

Location: Raifa Bogoroditsky monastery.

Required level of Russian as a foreign: B1-B2.

Trained knowledge and skills:

a) Grammar and morphology: types of verbs (formation and meaning); compound sentence, declension of nouns, direct and indirect speech.

b) Vocabulary: archaisms, historicisms, phraseological units.

c) Speech practice: building questions to request information, roleplaying a dialogue.

d) Writing: completion of the travel card.

e) Listening: listening to the guided tour and the introductory text.

f) Reading: learning and searching, orientated at searching the key information.

Manual for participants - the guide for the participants of the quest:

"If you are the first to complete all the tasks and you will get the treasure of the Raif monastery. Be careful, time in the past is limited. Only the fast ones can stay there. For every mistake or delay you will be moved to the present. If you find it difficult to answer, ask the people around you or search the Internet."

Participants also get a map of the monastery with the names of the objects.

Prelocation "GATEWAY TO THE PAST»

"We are with you now in 2018. To solve the mystery of this place, we need to go to the XVII century."

Task 0.1. Listen to the story of this place. Fill in your worksheets with the verbs:

Text for work (a fragment in Russian):

Raifa monastery in the middle of XVII century. The founder of the monastery the monk Filaret, who after the death of his parents a monk. He an ascetic way of life, away from people, so he left Moscow. He Kazan, in Spaso-Preobrazhensky monastery for life.

Task 0.2. To open the gate in the past, it is necessary to imagine this story as if it is happening in front of your eyes. "Be careful, time in the past is limited. Only the fast ones can stay there. For every mistake or delay, you will be moved closer to the present."

\section{LOCATION 1.THE CHURCH OF THE GEORGIAN MOTHER OF GOD}


Table 1. Join perts of complex sentences

1. Raifa Monastery has always attracted many pilgrims,

A. which was brought to Raifa

2. In the middle of the 17 th century, , one of the best Kazan

Б. although the whole Monastery was icon painters made a list of the revered icon. destroyed after the Revolution

3. About the icon, , many miracles have been told.

B. because the miraculous icon was kept in it.

4. A man came and prayed before the icon,

$\Gamma$. if he wanted to heal diseases and regain

4. A man came and prayed before the icon, health

5. The icon was saved by scientists of the Kazan University,

Д. when Raifa Monastery was founded

5. Kazan scientists found the icon and transferred it to the temple of

E. where the icon was kept until the revival Yaroslavl Saints at the Arsk cemetery, of the Monastery.

TASK 1-2. ANSWER THE QUESTION. ON WHAT WERE THE ICONSPAINTED?

ANSWER 1: THE WOOD

LOCATION 2.HOLY SOURCE

Table 2. Read these idioms. What's the one word missing here? Insert it in the correct case. Name the place in raifa that is associated with this word.

\begin{tabular}{|c|c|}
\hline 1. Quieter than ___, lower than grass & $\mathrm{E}$ \\
\hline 2. How ___ flows through your fingers. & 3 \\
\hline 3. Released dry from & $\mathrm{B}$ \\
\hline 4. Much __ has flowed since that time. & Б \\
\hline 5. It was written with pitchforks on the surface of the & A \\
\hline 6. Kissel made on the seventh & $\Gamma$ \\
\hline 7. Carry ___ in a sieve. & Д \\
\hline 8. Like a fish in & И \\
\hline 9. Hide the ends in & Ж \\
\hline
\end{tabular}

ANSWER 2: THE LAKE

LOCATION 3. TRINITY CATHEDRAL

TASK 3-1. DETERMINE WHAT KIND OF BUILDING WE ARE TALKING ABOUT? INSERT THE WORD IN THE CORRECT CASE IN THE TEXT.

The last buildings of the Raifa hermitage were this building and the Trinity Cathedral.

The construction of this building was begun in 1889 with the funds and by contract of the famous Kazan philanthropist Mikhail Timofeevich Atlashkin.

According to legend, the abbot Benjamin, the abbot of the monastery, was not sure of the need to build this building. 
ANSWER 3: THE BELL TOWER

LOCATION 4.THE CHURCH IN THE NAME OF REVEREND FATHERSMASSACREDIN SINAI AND RAIFA (PUZZLE)

TASK 4-1. DO YOU KNOW WHAT THESE WORDS MEAN? FIND COGNATES TO THE WORDS OF THE MONASTIC LIFE.

the Cathedral , the Chapel ,the Matins , the Liturgy, the Mass , the Supper the Sound of Bells -

TASK 4-2. THINK WHAT UNITES ALL THESE WORDS? WHAT ACTION IS ACCOMPANIED BY THESE WORDS?

\section{ANSWER4: TO PRAY, PRAYER}

LOCATION 5.THE BELL TOWER

TASK 5-1. YOU'RE IN THE XVII CENTURY, WHERE LIFE IS DIFFERENT FROM THE MODERN ONE. AND THINGS HERE ARE DIFFERENT, TOO.

Participants receive pictures with illustrating and namingthe Antiques: кафтан, палица, сундук, алтын, пищаль, рукавицы.

TASK 5-2. THIS OBJECT CAN INCLUDE ALL THE REST ONES INSIDE.

ANSWER 5: THE CHEST

Final

"All tasks completed. Get an old message that you need to supplement by the received tips."

Where is the entrance, there is the exit. How many floors - so much testing. Behind your back is ( 3 ). Turn right, then go to $(2$ ). Many years ago monk brothers (4 ) there. There near the last (1 ) you will find $(5$ ) .

\section{Summary}

The quest, like any didactic game suggests an active form of learning, which is formed into simulating and modeling activities (in our case, speech activity) on the basis of the studied language systems, phenomena and processes, which simultaneously connects the cognitive and entertaining beginnings. The activity of this kind presupposes the existence of rules, a fixed structure and mechanics of the game, and the assessment system. In the functioning of these elements, each participant and the team as a whole are united by solving the main task and focus their behavior on winning. The hidden element that makes the game didactic is the presence of a training task, masked and implemented implicitly through the game task, game actions and rules, when the natural desire to win becomes the motive of learning. In one case, the basis of the game content is didactic material, the actions with which being clothed in the form of a game. In another case, the didactic material is introduced as an element in the game activity, which is the main one both in form and content.

As for the specifics of the quest projects in the methodology of teaching foreign languages and specifically Russian as a foreign language, it is necessary to take into account here the immediate tasks of mastering the speech and grammatical skills of the target language. The most important task of the quest game technology in mastering a foreign language is eliminating psychological barriers of perception and speech production, which is facilitated by the implicit educational goal against the background of the game [Arkhipova, p. 28].

The second most important task is the ability to train the reaction to non - standard communicative situations, and in case of impossibility of a direct solution-the ability to find a workaround.

Includinglessons-quests in the educational process allows you to: 1) develop the skills of human information activities; 2) to form a positive emotional attitude to the learning process, to increase the motivation of learning, the quality of learning the subject; 3 ) to develop the creative potential of the players and the critical thinking .

\section{Conclusions}

Gamification of the educational process has long been an effective approach to learning through simulating the trained actions and reconstructing the necessary situations. Game for adult learners to no less extent than for children, can greatly facilitate the process of assimilating the material as by removing psychological barriers, masking the learning tasks behind the game ones, as by captivating excitement and competition (on the usefulness of active methods in 
particular, [Agasieva I.R. 2016; Vishlenkova S.G., Levina E.A. 2016; Calık \& Birgili, 2013]). Methodology of teaching foreign languages has long been used sporadically different types of didactic games, role-playing games. At the same time, the massive spread of the quest form in the entertainment and tourism industry could not but attract the attention of teachers seeking to turn well-established games into a single quest-oriented whole.

The effectiveness has been showed by using such forms of work as a lesson-quest. The quest in teaching Russian as a foreign language is able to simultaneously accommodate several interactive approaches, to implement competition, controlled spontaneity and to be flexible and adapted to a specific group of students.

\section{Acknowledgements}

The work is performed according to the Russian Government Program of Competitive Growth of Kazan Federal University.

\section{References}

Alpeisso, G. T., Dossanova, K. K., Baigonyssova, K. O. \& Kozhenova, L. Z. (2018). National identity in the modern education of Kazakhstan. Opción, 34(85-2), 544-568.

Arkhipova, Ye. A. (2004). Fundamentals of Student Speech Development Techniques. Moscow: Verbum-M Edition, 192

Agasieva, I. R. (2016). The need to use interactive methods in teaching foreign language to students of non-language faculties. Modern high technologies, 1, 55-58.

Baroughi, E. \& ZAREI, M. H. (2013). The Ranking of Effective Factors on Efficiency of Commercial Adsin Attracting Viewers in Tehran, Iran. UCT Journal of Management and Accounting Studies, 1(1), 22-28.

Bochina, T. \& Adamka, (2015). Proverb and Mythopoetic Model of the World [Prislovie a myto-poeticky model sveta]. XLinguae, 8(2), 18-28.

Calık, B. \& Birgili, B. (2013). Multiple intelligence theory for gifted education: Criticisms and implications. Journal for the Education of Gifted Young Scientists, 1(2), 1-12.

Galiulina, I. R., Yapparova. V. N. \& Starostina, O. V. (2016). Foreign student's social competence formation on russian speech listening lessons (by the example of regional studies texts). Modern Journal of Language Teaching Methods, 37-42.

Kapralova, Yu. V., Moskaleva, L. A., Frolova, S. A. \& Shakhmatova, T. S. (2018). The man playing: linguistic studies and Russian grammar in quests and game tasks. Kazan: Kazan. uni, Edition, 150.

Litdewood, W. (2002). Communicative Language Teaching. Cambridge: Cambridge university press, -60.

Makleeva, E. A., Akhmetzyanova, L. M. \& Yan Zhike. (2018). Integration of teaching methods and principles of selection of language material in classes of Russian as a foreign language. AD ALTA, 8(1), 172-175.

Marsha Ludden. (2002). Effective communication skills. - London: JIST Publishing. 128.

Savchenko, T. (2007). Methodology of Russian as a foreign language. Teaching Grammar. Russian Language, 7(535), 20-26.

Varlamova, M. Yu., Miftakhova, A. N. \& Bochina, T. G. (2016). Interactivity in teaching a foreign language. Journal of Language and Literature, 7(3), 190-194.

Vargas, F., Benincasa, T., Cian, G. \& Martignon, L. (2019). Fostering Probabilistic Reasoning Away from Fallacies: Natural Information Formats and Interaction between School Levels. International Electronic Journal of Mathematics Education, 14(2), 303-330. https://doi.org/10.29333/iejme/5716

Vishlenkova, S. G. \& Levina, E. A. (2016). Activation of educational and cognitive activity of bachelor students using interactive methods in the process of teaching a foreign language, Philological Sciences. Questions of theory and practice, 11(65), 192-195. 